\title{
PARADIGMA KONSELING BERPERSPEKTIF GENDER PADA KASUS KEKERASAN DALAM RUMAH TANGGA
}

\begin{abstract}
Sigit Sanyata ${ }^{1}$
Abstrak

Persoalan bias gender menimbulkan berbagai permasalahan, seperti marginalisasi, subordinasi, stereotip, beban kerja, dan kekerasan. Pergeseran paradigma dalam konseling yang semula berorientasi pada intrapsikis bergeser ke arah ekstrapsikis yang akan mempengaruhi keadaan emosional dan phisik lebih baik, membawa implikasi mendasar pada pelaksanaan konseling. Artikel ini melakukan kajian pandangan gender, khususnya feminis, pada kasus kekerasan dalam rumah tangga.
\end{abstract}

Kata kunci: gender, kekerasan rumah tangga

\begin{abstract}
The issues of gender bias, such as marginalization, subordination, stereotypes, work, and violence. The counseling paradigm shift from intrapsychic oriented intrapsychic into extrapsicism oriented, affect emotional and physical states better, bringing fundamental implications for counseling. This article reviews the gendered outlook, especially feminist, in domestic violence cases.
\end{abstract}

Keywords: gender, domestic violence

\section{PENDAHULUAN}

Perbedaan jenis kelamin tidak dapat dipungkiri membawa peran dan fungsi berbeda. Pemahaman tentang gender dan seks berimplikasi pada perilaku masyarakat terhadap relasi gender, tetapi yang lebih mendasar adalah munculnya bias gender dalam konstruksi sosial masyarakat yang menempatkan peran gender secara tidak setara. Ketidaksetaraan ini dipengaruhi oleh stereotype yang terbangun dalam masyarakat sehingga memunculkan ketimpangan relasi gender. Pembagian kerja berdasarkan gender masih menempatkan posisi dan peran perempuan dalam sektor domestik, kalaupun perempuan memiliki kesempatan untuk berkarir di ruang publik maka perempuan harus mampu eksis secara optimal di tempat kerja maupun sebagai ibu rumah tangga. Pada saat itu perempuan memiliki beban ganda (double burden), di satu sisi mereka perlu berusaha sendiri tetapi di sisi lain dituntut lebih konsisten untuk mengasuh anak dan mengurus keluarga (Nasarudin Umar, 2001).

Laki-laki dianggap lebih leluasa melakukan kegiatan produktif, disamping karena mereka (laki-laki) terbebas dari fungsi-fungsi reproduktif seperti menstruasi, mengandung, melahirkan, menyusui, juga karena budaya masyarakat menuntut laki-laki berperan lebih besar di sektor non-keluarga (non family role obligations). Budaya patriarkhi memiliki kontribusi yang cukup kuat dalam mengembangkan bias gender. Handayani dan Sugiarti (2002) mengemukakan bahwa selain hegemoni patriarkhi atas ketidakseimbangan gender juga disebabkan oleh sistem kapitalis yang berlaku, yaitu siapapun yang memiliki modal besar/kuat maka dialah yang menang, kondisi ini dapat dianalogikan bahwa lakilaki yang dilambangkan lebih kuat daripada perempuan akan mempunyai peran dan fungsi yang lebih besar.

\footnotetext{
${ }^{1}$ Mahasiswa Program Doktoral Universitas Pendidikan Indonesia
} 
Persoalan bias gender merupakan problem sosial yang muncul dalam dinamika perkembangan masyarakat. Bias-bias gender akhirnya membawa persoalan gender menjadi lebih rumit dan tidak mudah untuk diurai, hal ini tidak lebih karena masyarakat menempatkan makna gender seperti halnya jenis kelamin yang melekat secara permanen dan tidak dapat dipertukarkan. Keberadaan gender dalam perspektif humaniora memandang permasalahan gender ada sejak manusia diciptakan. Terjadinya bias gender lebih disebabkan karena konsep pemahaman gender masih sebatas pada status yang melekat pada jenis kelamin, padahal dalam kerangka yang lebih luas gender dipahami sebagai status yang diperoleh atau diperjuangkan.

Jenis kelamin berhubungan dengan aspek-aspek biologis yang mengakibatkan perbedaan karakteristik pada laki-laki dan perempuan berdasarkan kromosom, anatomi reproduksi, hormon dan karakter biologis lainnya, sedangkan gender merupakan aspek sosio-kultural yang melekat pada laki-laki dan perempuan (maskulinitas dan feminitas). Perbedaan antara perempuan dan laki-laki secara esensial berimplikasi dalam berbagai persoalan kehidupan. Berbagai bentuk ketidakadilan gender diuraikan oleh Fakih (2008), yaitu:

1. Marginalisasi. Marginalisasi berarti proses yang menyebabkan perempuan terpinggir dalam segala hal. Ada beberapa jenis dan bentuk, tempat dan waktu, serta mekanisme proses peminggiran kaum perempuan karena perbedaan gender, antara lain peminggiran dalam bidang ekonomi.

2. Subordinasi. Subordinasi dalam hal ini adalah penomorduaan pada salah satu jenis kelamin, umumnya pada perempuan. Pandangan gender telah menimbulkan subordinasi terhadap perempuan. Perempuan dianggap sebagai bagian dari laki-laki, dan bukan sebagai satu kesatuan yang utuh. Laki-laki adalah pemimpin bagi perempuan sehingga perempuan harus selalu tunduk pada kemauan laki-laki.
Dengan demikian posisi perempuan ada di bawah laki-laki atau tidak setara.

3. Stereotip. Stereotip adalah pelabelan atau penandaan terhadap suatu kelompok tertentu, dalam hal ini perempuan. Dalam kerangka permasalahan gender, stereotip sering menjadi sumber ketidakadilan gender dalam berbagai bentuk. Banyak sekali stereotip yang terjadi di masyarakat yang dilekatkan kepada umumnya kaum perempuan sehingga berakibat menyulitkan, membatasi, memiskinkan, dan merugikan kaum perempuan.

4. Beban kerja. Peran gender perempuan dalam anggapan masyarakat luas adalah mengelola rumah tangga, sehingga banyak perempuan yang menanggung beban kerja domestik lebih banyak dan lebih lama dibanding kaum laki-laki.

5. Kekerasan. Kekerasan merupakan invasi atau serangan tehadap fisik maupun integritas mental psikologis seseorang yang dilakukan terhadap jenis kelamin tertentu, umumnya perempuan sebagai akibat dari perbedaan gender. Pada dasarnya kekerasan gender disebabkan oleh ketidaksetaraan kekuatan yang ada dalam masyarakat. Umumnya kekerasan akibat bias gender dilakukan oleh laki-laki terhadap perempuan, akibat kondisi fisik perempuan yang lebih lemah terhadap lakilaki, serta atribut-atribut yang melemahkan perempuan. Kekerasan yang disebabkan oleh bias gender ini disebut gender-related violence.

Secara faktual kekerasan terhadap perempuan menunjukkan bukti-bukti yang merefleksikan ketimpangan kekuatan sosial budaya antara laki-laki dengan perempuan. Bagaimanapun juga harus disadari dan dipahami bahwa kekerasan terhadap perempuan dan relasi personal merupakan tindakan kriminal yang memberikan peluang bagi korban untuk menuntut pelaku di pengadilan. Sinclair (1999) mempertegas bahwa perempuan merupakan pihak paling rentan terhadap kekerasan dalam rumah tangga maupun dalam relasi personal. Lebih lanjut Sinclair juga menambahkan bahwa derajat keseriusan masalah kekerasan 
menunjukkan peningkatan sepanjang waktu, sehingga bukan tidak mungkin menimbulkan kerusakan permanen pada korban. Dampak psikologis korban adalah dapat menampilkan tingkah laku merusak diri (self-destructive behavior). Satu hal yang musti diingat adalah bahwa kekerasan terhadap istri atau pasangan bukan merupakan fenomena baru tetapi merupakan fenomena yang telah berlangsung lama.

Lingkup kekerasan terhadap perempuan memiliki dimensi yang cukup luas dan tidak terbatas, namun untuk mengkaji secara rinci maka kekerasan dapat di sajikan dalam tiga wilayah yaitu kekerasan dalam masyarakat, kekerasan oleh negara dan kekerasan dalam rumah tangga. Ketiga wilayah merupakan upaya untuk membagi lingkup kekerasan kepada perempuan agar memiliki perpspektif yang lebih terfokus tanpa bermaksud memisahkan permasalahan, karena pada akhirnya penuntasan masalah gender tidak hanya melibatkan personal tetapi lingkungan sosial budaya dan komitmen dari Negara. Laporan dari Komnas Perempuan (2002) berdasarkan identifikasi peta kekerasan di berbagai pelosok wilayah Indonesia, memaparkan bahwa bentuk-bentuk kekerasan terhadap perempuan terbagi dalam delapan jenis, yaitu sebagai berikut.

1. Kekerasan fisik; dalam relasi personal bentuk kekerasan yang dialami oleh perempuan, antara lain; tamparan, pemukulan, penjambakan, dorongan kasar, menginjak, menendang, mencekik, lemparan benda keras, penyiksaan dengan benda tajam (seperti; pisau, gunting, setrika). Dalam konteks relasi kerja dan kemasyarakatan, seperti; penyekapan calon pekerja di tempat-tempat penampungan, pelecehan secara seksual.

2. Penyiksaan mental; makian atau penghinaan secara berkelanjutan yang berujuan untuk merendahkan harga diri korban, bentakan disertai ancaman untuk menimbulkan rasa takut, larangan untuk beraktivitas secara sosial dan pembatasan terhadap ruang gerak perempuan.

3. Deprivasi ekonomi; khusus perempuan yang berstatus sebagai ibu rumah tangga adalah tidak dicukupinya nafkah secara rutin untuk mencukupi kebutuhankebutuhan dalam rumah tangga. Dipaksa untuk tidak bekerja, atau penguasaan terhadap hasil kerja istri untuk kepentingan pribadi merupakan kekerasan dalam masalah ekonomi.

4. Deskriminasi; di sektor keluarga pihak perempuan dibatasi perannya. Pada sebagian masyarakat masih membagi peran domestik untuk perempuan, sementara sektor publik menjadi tanggung jawab laki-laki.

5. Serangan seksual; merupakan kekerasan yang bernuansa seksual termasuk di dalamnya mempunyai makna seksual (pelecehan seksual) maupun berbagai bentuk pemaksaan hubungan seks (perkosaan). Serangan seksual dalam situasi konflik dan represi politik, tahanan atau musuh perempuan mejadi korban cara-cara penyiksaan yang secara sengaja ditujukan pada organ-organ reproduksi dari tubuh korban.

6. Perbudakan seksual; perbudakan seksual adalah salah satu bentuk serangan seksual yang bersifat sistematis dan muncul dalam situasi perang atau konflik bersenjata (Komnas Perempuan, 2002: 43). Perbudakan seksual di era penjajahan Jepang, masa berlakunya DOM (di Timtim dan Aceh) merupakan contoh-contoh perbudakan seksual di dalam perang dan konflik bersenjata.

7. Intimidasi berbasis gender; di wilayah operasi militer (DOM) ditemukan beberapa kasus di mana perempuan menjadi sasaran khusus dari berbagai tindak ancaman, intimidasi bahkan serangan secara fisik karena korban dianggap melanggar ketentuan-ketentuan sosial tertentu, seperti cara berpakaian atau perilaku seksual yang tidak mau diterima oleh pihakpihak tertentu dalam masyarakat (Komnas Perempuan, 2002: 43).

8. Perdagangan perempuan; perempuan 
Indonesia baik yang sudah dewasa maupun di bawah umur banyak yang menjadi korban praktik-praktik perdagangan perempuan, apalagi dalam situasi krisis yang berkepanjangan. Bentuk perdagangan manusia yang mengancam perempuan adalah dipekerjakan secara paksa sebagai pengemis, pengedar narkoba, pekerja rumah tangga, kawin kontrak transnasional (Komnas Perempuan, 2002: 44).

Wilayah kekerasan terhadap perempuan pada sektor yang paling kecil adalah rumah tangga. Kekerasan dalam rumah tangga merupakan fenomena yang mengundang keprihatinan berbagai pihak. Puncak keprihatinan tersebut diwujudkan dalam bentuk diberlakukannya UU No. 23 tahun 2004 tentang Penghapusan Kekerasan Dalam Rumah Tangga semenjak tanggal 22 September 2004. Undang-Undang tersebut diharapkan menjadi jaminan hukum bagi perlindungan anggota keluarga dari segala tindak kekerasan dalam rumah tangga. Namun demikian secara faktual laporan angka kekerasan dalam rumah tangga justru mengalami kenaikan. Kekerasan dalam rumah tangga merupakan fenomena lintas kelas, lintas suku dan lintas agama. Laporan tentang kekerasan dalam rumah tangga dari tahun ke tahun meningkat baik secara kuantitas dan kualitas. Intervensi kepada korban kekerasan telah dilakukan dengan berbagai metode dan strategi, dari konseling krisis, hingga pendampingan di lembaga hukum dan kepolisian. Namun demikian upaya tersebut masih tetap memunculkan catatan tingginya kasus kekerasan dalam rumah tangga. Salah satu mekanisme yang dapat ditempuh untuk menekan angka KDRT adalah dengan pemberdayaan masyarakat untuk membantu mencegah terjadinya kekerasan dalam rumah tangga.

\section{PEMBAHASAN}

Pergeseran paradigma dalam konseling yang dikemukakan oleh Bradley (2001) bahwa konseling yang semula berorientasi pada intrapsikis bergeser ke arah ekstrapsikis yang akan mempengaruhi keadaan emosional dan phisik lebih baik, membawa implikasi mendasar pada pelaksanaan konseling. Pendekatan lintas disiplin menjadi tuntutan dalam melakukan program-program konseling. Arah baru paradigma konseling membawa keterbukaan wawasan bahwa penyelesaian problematika yang dihadapi oleh konseli tidak saja dipahami dalam kondisi psikisnya tetapi konteks di mana konseli berada turut membantu dalam mengatasi problematika yang dihadapi. Secara lebih luas dapat dijelaskan bahwa proses konseling akan senantiasa bersentuhan dengan komponen-komponen eksternal yang turut membangun lingkungan kehidupan konseli, tentu saja komponen di luar konseli menjadi tujuan rujukan bagi konselor yang menangani problematika konseli. Hal yang menarik dalam paradigma ini adalah adanya intervensi krisis oleh konselor baik secara individual, kelompok maupun institusional. Konseling tidak lagi berlangsung secara intrapsikis tetapi menambahkan proses ekstrapsikis sebagai kelanjutan dari proses konseling. Intervensi krisis yang dilakukan konselor lebih efektif jika mengkolaborasi dengan profesi lain seperti bidang hukum, psikologi, kedokteran maupun kepolisian, sehingga ketuntasan permasalahan dapat tercapai.

Kiselica dan Robinson (2001) menjelaskan bahwa peran konselor dalam menjalankan advokasi sosial dilatarbelakangi oleh dua faktor, yaitu: a) konselor bekerja dalam dalam konteks sosial di mana permasalahan terjadi, b) kerja konselor terkait erat dengan dengan upaya profesional untuk membantu konseli keluar dari situasi tidak adil dan tidak setara dalam masalah yang dihadapi. Tulisan tersebut secara eksplisit memiliki makna; Pertama, konselor dalam posisi ruang dan waktu berada dalam wilayah sosial di mana konseli dan masalah tersebut muncul/berada sehingga pendekatan dalam interaksi sistem sosial menjadi titik tolak dimana seorang konselor bekerja; Kedua, konselor bertanggung jawab untuk dapat mengembangkan konselinya sehingga mendapatkan perlakuan secara setara dan adil sesuai hak-haknya dengan tidak mengabaikan perbedaan gender yang melekat 
pada konseli.

Kiselica \& Robinson (2001) mengemukakan bahwa konselor dituntut untuk memiliki perikemanusiaan maka pendekatan terapi humanis, terutama adalah person centered model (non directive counseling) yang dikembangkan oleh Carl Rogers. Dalam pendekatan ini konselor memberikan kemerdekaan sepenuhnya kepada konseli untuk mengekspresikan apa saja yang dikehendaki konseli. Pendekatan ini ditujukan agar tidak menciptakan kondisi yang mengancam bagi konseli sehingga konseli merasa terlindungi dan memiliki rasa aman untuk mengutarakan segala sesuatu yang menjadi permasalahannya. Corey (2005) mendeskripsikan bahwa dalam person centered model konselor bertindak untuk: congruence, unconditional positive regard dan empathic. Kondisi ini akan memberikan kenyamanan bagi konseli dalam proses konseling.

Konsep tentang konseling multikultural, konseling lintas budaya dan spiritualitas dalam konseling menyadarkan kembali bahwa konseling tidak dapat dipahami secara parsial, klinis dan dalam garis budaya tertentu. Pendekatan konseling ekologis merupakan reaktualisasi konseling dalam kerangka kerja membangun dan mengembangkan epistemologi ilmu-ilmu dalam kaidah sains dan praksis. Konseling yang memiliki interaksi dinamis dengan lingkungan sosial berimplikasi pada bidang garapan yang tidak hanya dalam kawasan pendidikan tetapi adanya tuntutan secara responsif untuk selalu reaktif terhadap isu-isu dalam masyarakat. Analisis ini membawa konsekuensi bahwa proses pendampingan kepada konseli harus dilakukan oleh konselor dalam layanan konseling. Salah satu kompetensi dasar konselor yang seirama dengan kaidah tersebut adalah seorang konselor harus memahami kompleksitas interaksi individu-lingkungan dalam ragam kontek sosial budaya. Kompetensi ini mengindikasikan bahwa konselor dituntut untuk mampu meng-assess, mengintervensi, dan mengevaluasi keterlibatan dinamis dari keluarga, lingkungan sekolah, lembaga sosial, dan masyarakat sebagai faktor yang berpengaruh terhadap keberfungsian individu di dalam sistem. Tuntutan dari kondisi ini memposisikan konselor:

1. Memahami isu dan konteks perubahan mekanisme sosial serta memiliki kemampuan membaca arah paradigma perubahan nilai dan norma dalam masyarakat.

2. Membuat jaringan dalam sistem dan unit sosial yang berkaitan dengan wilayah kerja konseling.

Meningkatkan profesionalisasi, untuk menjamin sistem layanan konseling yang memenuhi standar dan kode etik profesi sehingga konselor merupakan salah satu profesi yang dapat diterima dalam masyarakat untuk mengembangkan interaksi sosial. Kompetensi yang dimiliki oleh pendamping tentunya tidak berarti banyak jika tidak ada dukungan dari masyarakat sosial untuk terlibat dalam pencegahan kekerasan dalam rumah tangga. Konsep ini seirama dengan pola konseling dengan pendekatan sistem (system approach) (Corey, 2005).

Secara umum konseling berperspektif gender tidak jauh berbeda dengan konseling bagi komunitas-komunitas tertentu. Hal mendasar yang penting untuk dipahami dalam proses konseling feminis adalah tidak sekedar memasukkan isu-isu gender ke dalam proses konseling tetapi dibarengi dengan pemahaman yang mendalam tentang konsepkonsep kesetaraan gender, perspektif nilai pada perempuan dan memandang setiap orang memiliki kemampuan untuk menentukan pilihan dan membuat keputusan secara mandiri. Berbagai karakteristik konseling feminis harus sensitif terhadap;

1. Pengakuan bahwa ada pengaruh konteks sosial, politik, ekonomi, dan sejarah dalam membentuk kehidupan, pengalaman dan perilaku laki-laki dan perempuan di keluarga;

2. Memahami secara fokus tentang gender 
dalam kehidupannya dan bagaimana gender turut berperan dalam membedakan pengalaman hidup laki-laki dan perempuan;

3. Memahami sosialisasi peran jenis kelamin;

4. Kritik pada praktek konseling dan konstruk teori yang kurang menghargai kehidupan perempuan dan pandangan tentang perilaku perempuan yang distereotypekan lemah, pasif atau masokhis;

5. Dalam terapi memberikan nilai yang sama terhadap pilihan dan pengalaman hidupnya antara laki-laki dengan perempuan;

6. Kesadaran gender merupakan kekuatan mendasar dalam kehidupan sosial dan keluarga;

7. Menekankan pada kemampuan konseli, memberi kesempatan untuk menguji pilihan yang telah ditetapkan;

8. Menekankan hubungan yang setara dalam keluarga;

9. Memotivasi kepercayaan diri konseli dalam konseling dan menekankan prinsip kesetaraan antara konseli dengan konselor.

Gilbert dalam Jill Elaine Rader (2003)

mengajukan dua prinsip konseling feminis, yaitu sebagai berikut.

1. Personal memiliki posisi secara politis dalam masyarakat, konseli maupun konselor berusaha membangun konsep tentang nilai gender dan bagaimana konsep nilai tersebut telah berpengaruh pada konstruksi sosial.

2. Hubungan antara konseli dengan konselor setara. Menurut Gilbert (dalam Jill Elaine Rader 2003) prinsip kesetaraan antara konselor dengan konseli ditandai dengan kemampuan konselor untuk (a) memandang konseli sesuai dengan potensinya, (b) menginformasikan kepada konseli tentang proses konseling dan perannya secara tepat, (c) memakai berbagai strategi dan mengedepankan kemampuan dan kemandirian konseli (d) mendorong untuk mengekspresikan kemarahan, serta (d) menjadi model perilaku yang baik bagi konseli.

Marecek dan Hare-Mustin mendeskripsikan tiga prinsip konseling gender (orientation feminist to therapy), yaitu sebagai berikut (a) pendekatan untuk memunculkan kesadaran gender, konseli belajar membedakan antara problem perilaku dalam dirinya dengan konstruksi sosial yang terbangun dalam masyarakat. Pendekatan ini sama dengan pendapat Gilbert, the personal is political, (b) women-validating process, konseli belajar menilai pengalaman-pengalamannya dan mengenali kekuatan-kekuatan pada dirinya, serta (c) hubungan secara egaliter antara konseli dengan konselor ditujukan untuk mendorong kepercayaan dirinya, dan berperan aktif dalam proses konseling.

Worell and Johnson (1997) mengemukakan bahwa prinsip mendasar dalam konseling feminis adalah dari etika praktek psikoterapi sampai kepada strategi analisis sosial politik (Jill Elaine Rader, 2003: 12). Worell \& Johnson juga menambahkan pentingnya kesetaraan dan kerja sama khususnya dalam hubungan terapi konseling. Toni Sands (1998: 44) mengajukan analisis dasar konseling feminis yaitu, hubungan yang setara antara konseli dengan konselor (the egalitarian relationship), personal memiliki dimensi politis dalam masyarakat (the personal is political), berperspektif perempuan (valuing the female perspective).

Barbara Brown (2006: 23) menjelaskan prinsip-prinsip konseling feminis dalam empat kategori yaitu sebagai berikut ini, (a) memberikan perhatian pada keragaman perempuan sebagai individu (personal) dan identitas sosial, (b) endekatan untuk membangun kesadaran gender, (c) hubungan yang setara antara konselor dengan konseli, serta (d) proses membangkitkan kepercayaan dan harga diri pada perempuan.

Sama halnya dengan Gilbert, Marecek \& Hare-Mustin, Worell \& Johnson, Toni Sands dan Barbara Brown dalam Jill (2003) juga merumuskan prinsip konseling feminis dengan menekankan pada hubungan yang setara antara 
konselor-konseli.

Teori sentral konseling feminis adalah menekankan kesetaraan antara konseli dengan konselor (Jill Elaine Rader, 2003: 13). Pentingnya kesetaraan dibuktikan dengan riset yang dilakukan oleh Worell \& Johnson (1997) yang dapat mengungkap 16 dalil inti dari konseling gender, 6 dalil di antaranya menekankan pada aspek kesetaraan (egalitarian relationship). Tiga dari enam aspek tersebut adalah sebagai berikut ini: (a) Konseling feminis didasarkan pada pola yang jelas dan tepat tentang kesetaraan dalam proses konseling, (b) Konseling feminis ditujukan untuk membangun kesetaraan dan saling menghargai bukan hubungan yang otoriter, serta (c) Konseling feminis adalah proses kerja sama diantara konselor dengan konseli untuk bersama-sama menetapkan tujuan, arah dan langkah konseling.

Barbara Brown (2006) pendekatan konseling feminis (feminist counseling) memiliki tujuan yang mendasar untuk melakukan intervensi secara personal, keluarga dan komunitas yang mempengaruhi faktor kesehatan mental mereka (perempuan) yang disebabkan oleh intrapersonal, hubungan interpersonal, maupun lembaga. Tujuan jangka panjang dari pendekatan konseling feminis adalah membangun kekuatan personal-sosial dan resiliensi terhadap strategi menghadapi trauma dan stress pada masa lalu, sekarang, maupun masa yang akan datang.

Pendekatan konseling feminis dibangun dengan memperhatikan kaidah kemanusiaan dan penghargaan terhadap konseli sebagai individu yang memiliki kemampuan, kemandirian dan kreativitas. Salah satu pendekatan humanistik yang peka terhadap pengembangan diri konseli adalah konsep dari Rogers yang memfungsikan berkembangnya individu secara penuh. Tiga karakteristik pokok tentang hipotetis kepribadian terkait dengan implementasi konsep Rogerian adalah sebagai berikut ini, (a) setiap individu akan terbuka dengan pengalaman-pengalamannya, (b) individu hidup dalam kondisi sekarang, pengalaman hidupnya menjadikan sebuah proses mengembangkan diri, serta (c) Individu memiliki kepercayaan terhadap dirinya sendiri. (Blocher, 1974: 94).

Pandangan Rogers menyiratkan bahwa setiap individu (konseli) memiliki potensi positif dan kekuatan dalam dimensi waktu kekinian untuk mengembangkan diri. Dengan konsep ini, individu dibawa ke dalam pemahaman kekuatan-kekuatan diri untuk membangun struktur kepribadian yang mandiri. Implikasi konsep Rogers dalam konseling adalah, konseli diberi kesempatan untuk membuka diri terhadap pengalamanpengalamannya dan konselor memberikan kesempatan sepenuhnya agar konseli mampu mengeksplorasi kekuatan dan potensi dirinya. Mendengar secara aktif dengan empatik merupakan usaha konselor untuk membantu konseli membuka ketertutupan dirinya sehingga pada gilirannya konselor dapat memfasilitasi pengembangan diri.

\section{ISU-ISU DALAM PARADIGMA KONSELING BERPERSPEKTIF GENDER}

\section{Kompetensi Konselor}

Corey (2006) menjelaskan bahwa bagian terpenting dalam konseling adalah menjadi konselor yang efektif. Konselor yang efektif dapat dicapai dengan mempelajari bagaimana memperhatikan perbedaanperbedaan isu dan mampu mempraktekkan konseling secara tepat dari sudut pandang konseli. Peranan konselor adalah membantu membuat keputusan sesuai dengan sudut pandang konseli. Konselor yang memiliki perspektif multikultural akan secara efektif memahami kondisi budaya dan sosial politik konseli. Pemahaman ini dimulai dengan membangun kesadaran nilai-nilai budaya, bias dan sikap yang ditunjukkan konseli. Corey (2005: 24) mengemukakan bahwa dalam konseling multikultural memiliki tiga dimensi kompetensi, yaitu keyakinan dan 
sikap; pengetahuan; keterampilan dan strategi intervensi.

Keyakinan dan sikap konselor menyangkut persoalan bias personal, nilainilai dan masalah yang akan dihadapi serta kemampuan bekerja dalam perbedaan budaya, sedangkan faktor pengetahuan menyangkut kemampuan membangun komunikasi personal secara profesional untuk memberikan layanan kepada konseli dengan pemahaman latar belakang budaya yang beragam. Kompetensi yang tidak kalah pentingnya adalah ketrampilan memakai metode dan strategi konseling secara konsisten dalam latar perspektif budaya yang bervariatif agar mendukung efektivitas konseling.

Penguasaan standar kompetensi konselor merupakan kompetensi dasar bagi konselor feminis. Kompetensi dasar ini akan mendukung konselor feminis dalam melakukan konseling kepada perempuan korban kekerasan dalam rumah tangga. Feminist therapists dikembangkan dari beberapa teknik dan mengadopsi pendekatan tradisional untuk diadaptasi ke dalam model konseling feminis. Pokok-pokok pikiran pada konseling feminis yang membedakan dengan konseling pada umumnya adalah sebagai berikut.

1. Konseling feminis merupakan bagian dari pendekatan sistem, yang menekankan pada pemahaman individu dan pengaruhnya terhadap perkembangannya. Perubahan individu diharapkan dapat berpengaruh pada gender role socialization, masyarakat, keluarga dan sistem yang lain. Corey (2005) menyebut pendekatan ini sebagai systems perspective.

2. Konselor membantu konseli untuk menganalisis peran gender (Corey, 2005). Analisis peran gender bertujuan mengeksplorasi berbagai dampak dari peran gender yang selama ini menjadi keyakinannya.

3. Konselor mempunyai berbagai orientasi teoretik yang berkaitan dengan tidak memihak pada salah satu gender (gender fair), fleksibilitas kultural, mudah berinteraksi dan life span oriented.

4. Prinsip-prinsip konseling feminis didasarkan pada isu personal dan sosial, dimana kedua aspek saling mempengaruhi. Konselor memakai pertimbangan berdasar konsep nilai perempuan (feminist value) dalam memahami masalah dan hambatan konseli.

5. Hubungan antara konselor dengan konseli menekankan pemberdayaan dan kesetaraan perempuan.

\section{Pendekatan yang Digunakan}

David Geldard \& Kathryn Geldard (2001) menyatakan bahwa konseling yang efektif adalah bergantung pada kualitas hubungan antara konseli dengan konselor. Pentingnya kualitas hubungan konselor dengan konseli ditunjukkan melalui kemampuan konselor dalam kongruensi (congruence), empati (empathy), perhatian secara positif tanpa syarat (unconditional positive regard), dan menghargai (respect) kepada konseli. Hal ini mengakui bahwa akan ada perbedaan pendekatan dalam praktek konseling dan secara alami dipengaruhi pada pemilihan pendekatan yang dilakukan oleh sebagian konselor. Lebih lanjut David Geldard menambahkan bahwa pada dasarnya yang terbaik untuk saat ini adalah konsep yang diajukan oleh Rogers dalam bukunya Client-Centered Therapy. Artinya, pendekatan person centered therapy masih menjadi pendekatan yang efektif dipakai dalam proses konseling.

\section{Pertentangan Nilai-nilai antara Konselor dengan Konseli}

Dalam proses konseling hal penting yang tidak dapat dipungkiri adalah, antara konselor dengan konseli memiliki latar belakang perbedaan keyakinan dan nilai. Mengacu pada deskripsi tersebut maka salah satu kemampuan dasar konselor adalah tidak memberikan nilai/ cap tertentu (non-judgmental) karena konseli memiliki keyakinan dan nilai yang tidak sama dengan konselor. David Geldard (2001: 351- 
357) memberikan batasan tentang pengaruh keyakinan dan nilai konselor kepada konseli adalah sebagai berikut ini.

1. Mengubah individu adalah dengan memahami mereka dengan baik.

Proses konseling merupakan mekanisme perubahan perilaku yang didasarkan pada sistem nilai dan keyakinan yang dimiliki konseli. Konselor membantu konseli untuk menentukan pilihan-pilihan dan membuat keputusan dengan dilandasi komitmen serta pemahaman sepenuhnya akan kemampuan (potensi) dirinya. Dengan memahami konseli sesuai dengan kebutuhan mereka dilandasi dengan sistem nilai dan keyakinan dalam perspektif mereka (konseli), konseli merasa terfasilitasi, dihargai dan tumbuh kepercayaan diri.

2. Bersikap untuk non-judgmental.

Reaksi konselor muncul ketika terlibat sharing dengan konseli, reaksi positif merupakan reaksi yang seharusnya dilakukan namun seringkali reaksi negatif muncul ketika proses konseling berlangsung. Hal ini dapat disebabkan karena konselor belum sepenuhnya menerima konseli tanpa syarat atau bahkan perbedaan nilai diantara mereka. Respon negatif adalah wajar tetapi yang lebih penting adalah tidak menampakkan respons negatif tersebut sehingga konseli merasa tidak diterima atau ditolak. Reaksi terkejut, heran, kagum dan reaksi-reaksi yang lain harus direspons secara proporsional.

1. Membangun sistem nilai konselor.

Konselor yang efektif adalah konselor yang mampu memahami sudut pandang konseli, dengan tidak mengorbankan sistem nilai yang telah diyakini. Membangun sistem nilai konselor merupakan usaha untuk lebih memahami konteks pola berpikir dan budaya konseli yang menjadi panduan sitem nilainya.
3. Kebutuhan mendapatkan umpan balik.

Ketika memiliki perbedaan sistem nilai dan keyakinan, konselor dapat mendiskusikannya dengan teman sejawat atau konselor senior untuk memberikan masukan terhadap langkah-langkah yang telah dilakukan bersama konselinya.

Catatan penting yang perlu diperhatikan dan dikaji oleh konselor adalah, pertentangan nilai yang terjadi antara konselor dengan konseli memang tidak dapat dihindari tetapi ketika menyangkut nilai-nilai fundamental yang bersifat permanen maka konselor memiliki tanggung jawab untuk memasukkan sistem nilai tersebut kepada konseli sesuai dengan kaidah konseling. Nilai dasar yang tidak ada tawar menawar adalah masalah religiusitas (keimanan akan ke-Tuhanan), tetapi penanaman nilai tetap memperhatikan prinsip-prinsip konseling.

Corey (2005) menjelaskan bahwa terapi feminis tidak membatasi konselor laki-laki untuk berperan dalam konseling feminis. Salah satu syarat untuk menjadi konselor feminis adalah tidak memihak pada jenis kelamin tertentu (nonsexist). Dalam penjelasannya Corey (2005) berharap bahwa semua konselor ikut berusaha dan terlibat dengan konseli dalam rangka membangun kesadaran gender. Konselor (laki-laki) dapat menjadi pro-feminist therapy jika mereka dapat memahami dan mempraktekkan prinsipprinsip konseling feminis. Dalam proses konseling akan menemukan confront sexist behavior, redefinisi nilai tradisional feminitas dan maskulinitas, membangun hubungan yang setara dan aktif mendukung pemberdayaan perempuan.

Perempuan korban kekerasan berada dalam kondisi lemah, tidak berdaya, perasaan sendirian, hilangnya kepercayaan, dan harga diri memerlukan intervensi psikologis yang membuat konseli merasa dihargai dan masih ada orang lain memperhatikan dirinya. Corey (2005:171-174) mekanisme pendampingan harus memperhatikan prinsip- 
prinsip, kongruensi dan kejujuran, konselor dituntut untuk kongruen dan jujur dalam mengekspresikan perasaan, unconditional positive regard dan penerimaan dan memahami empati secara tepat. Corey juga mengingatkan bagian terpenting dalam konseling perspektif gender adalah menjadi konselor yang efektif dengan mempelajari bagaimana memperhatikan perbedaan-perbedaan isu dan mampu mempraktekkan konseling secara tepat dari sudut pandang konseli. Konselor yang memiliki perspektif multikultural akan secara efektif memahami kondisi budaya dan sosial politik konseli. Pemahaman ini dimulai dengan membangun kesadaran nilai-nilai budaya, bias dan sikap yang ditunjukkan konseli. Corey (2005: 24) menambahkan bahwa dalam konseling multikultural memiliki tiga dimensi kompetensi, yaitu: (1) Keyakinan dan sikap, (2) Pengetahuan, dan (3) Keterampilan dan strategi intervensi. Keyakinan dan sikap konselor menyangkut persoalan bias personal, nilai-nilai dan masalah yang akan dihadapi serta kemampuan bekerja dalam perbedaan budaya. Kemampuan konselor, sedangkan faktor pengetahuan menyangkut kemampuan membangun komunikasi personal secara profesional untuk memberikan layanan kepada konseli dengan pemahaman latar belakang budaya yang beragam. Kompetensi yang tidak kalah pentingnya adalah keterampilan dalam memakai metode dan strategi dalam menjelaskan tujuan konseling secara konsisten dalam latar perspektif budaya yang bervariasi.

Sinclair (1999) mengemukakan bahwa, agar konselor dapat memberikan intervensi yang efektif maka sebelum memberikan pendampingan kepada perempuan korban kekerasan harus didahului pemahaman terhadap nilai-nilai dan keyakinan tentang, (a) tidak dibenarkan tindakan kekerasan kepada perempuan dengan alasan apapun, (b) perempuan pada dasarnya tidak masokhis (suka disakiti, mendapatkan kenikmatan dari disakiti), (c) faktor utama yang menyebabkan perempuan tetap mempertahankan hubungan dengan pasangannya adalah peran tradisional perempuan yang diperoleh dari pranata sosial dalam masyarakat, (d) fokus pembicaraan awal adalah kekerasan yang terjadi bukan pada masalah-masalah inti dalam perkawinan, (e) siapapun yang menangani kasus perempuan korban kekerasan harus dapat menjadi model yang kompeten sukses dan asertif. Konselor mampu mengubah keyakinan konseli bahwa mereka bukan penyebab kekerasan itu terjadi dan mampu mengembangkan rasa percaya diri bahwa mereka dapat mengambil keputusan dan pilihan secara mandiri.

Egalitarian relationship, merupakan bentuk hubungan antara konselor dengan konseli (Worel \& Remer, 1992). Konseling dipandang sebagai proses kerjasama, dimana setiap individu dihargai dalam kapasitas kekuatan yang sama untuk mendiskusikan pokok masalah dan strategi pemecahan masalahnya (Toni Sands, 1998). Ditambahkan lagi bahwa walaupun metode kerjasama ini tidak mungkin untuk dilakukan pada setiap konseli tetapi proses ini harus tetap dilaksanakan sebagai salah satu tahap dalam konseling feminis. Egalitarian relationship menggunakan pendekatan dasar humanistik yaitu mendengar secara empatik, dorongan tak bersyarat (unconditional support), mutual respect, membantu membuka ketertutupan konseli secara tepat. Yang penting untuk diperhatikan adalah, konselor diharapkan membantu memahami secara rasional terhadap permasalahan yang dihadapi dan membebaskan dari prasangka. Sturdivant (1980) dalam Toni Sands (1998) mengajukan beberapa sikap konselor yang menunjukkan kemampuan memahami dalam perspektif perempuan korban seperti, empati, kerjasama, instuisi, interdependensi dan menekankan aspek hubungan yang seimbang. Valuing the female perspective, sebagai upaya konselor untuk memahami dan memfasilitasi konseli dalam mengekspresikan perasaannya sesuai dengan nilai yang diyakininya.

\section{PENUTUP}

Perkembangan pendekatan konseling pasca psikoanalitik, behavioristik dan 
humanistik adalah post modern. Pergeseran paradigma konseling menuju pada konsep developmental dan pemberdayaan walaupun pada kasus-kasus tertentu pendekatan sebelumnya masih dipandang cukup efektif dalam membantu menyelesaikan masalah konseli. Terapi feminis berkembang di tengahtengah situasi sosial yang di mana isu kesetaraan gender mulai digulirkan. Perkembangan terapi feminis banyak dipengaruhi oleh gerakan sosial sehingga bangunan teorinya merupakan upaya untuk mengatasi ketimpangan sosial dan pemberdayaan perempuan. Inti konseling berperspektif gender adalah kesetaraan, penghargaan terhadap individu dan berperspektif perempuan. Namun demikian kontribusi pendekatan konseling humanistik turut berpengaruh kuat dalam konseling berperspektif gender.

\section{DAFTAR PUSTAKA}

Brown, B. (2006). Feminist therapy. USA: American Psychological Association.

Chaplin, J. (1997). Counselling and Gender: Handbook of Counseling. (Edited by Stephen Palmer, $2^{\text {nd }}$ edition). London: British Association for Counseling.

Corey, Gerald. (2005) Theory and Practice of Counseling and Psychotherapy. Belmont, CA: Brooks/Cole-Thomson Learning.

Fakih, M. (2008). Analisis Gender dan Transformasi Sosial. Yogyakarta: Pustaka Pelajar.

Geldard, D., \& Geldard, K., (2001). Basic Personal Counselling: A Training Manual for Counsellors. Prentice Hall. Frenchs Forest: Australia.

Handayani, T. \& Sugiarti. (2002). Konsep dan Teknik Penelitian Gender. Malang. UMM Press.

Kiselica, M.S. \& Robinson, M. (2001). Bringing Advocacy Counseling to Life: The History, Issues, and Human Dramas of Social Justice Work in Counseling. Journal of Counseling \& Development, 79(4), 387397.
Komnas Perempuan. (2002). Peta Kekerasan: Pengalaman Perempuan Indonesia. Ameepro. Jakarta.

Umar, Nasaruddin. (2001). Argumen Kesetaraan Jender: Perspektif A-Qur'an. Penerbit: Paramadina. Jakarta.

Rader, J., \& Gilbert, L. A. (2005). The egalitarian relationship in feminist therapy.Psychology of Women Quarterly, 29(4), 427-435. Retrieved from https://search.proquest. com $/$ docview $/ 36831885$ ? accountid $=25704$

Sands, T. (1998). Feminist counseling an female adolescents: Treatment strategies for depression. Journal of Mental Health Counseling, 20(1), 42-54. Retrieved from https://search.proquest.com/ docview/198716529? accountid=25704

Sinclair, D. (1999). Memberdayakan Perempuan Korban Kekerasan Dalam Rumah Tangga/ Hubungan Intim. (Terjemahan: Betariani \& Kristi Poerwandari). Program kajian Wanita PPs. Universitas Indonesia.

Sinclair, D. (1999). Memberdayakan Perempuan Korban Kekerasan Dalam Rumah Tangga/ Hubungan Intim. (Terjemahan: Betariani \& Kristi Poerwandari). Program kajian Wanita PPs. Universitas Indonesia. 